\title{
Evaluation of the effectiveness of histopathological verification of the endometrium by means of an outpatient aspiration biopsy
}

\author{
'Chair of Gynecology and Obstetrics, Jagiellonian University in Krakow, Krakow, Poland \\ ${ }^{2}$ Voivodeship Sanitary-Epidemiological Station in Krakow, Krakow, Poland \\ Correspondence: Professor Kazimierz Pityński, MD, PhD, Chair of Gynecology and Obstetrics, Jagiellonian University in Krakow, 23 Kopernik Street, 31-501 Krakow, Poland, e-mail: pitynski@wp.pl
}

\begin{abstract}
Objectives: 1) Examining the effectiveness of an outpatient aspiration biopsy from the uterine cavity in the context of satisfactory sampling. 2) Assessing risk factors of obtaining a non-diagnostic sample. 3) Search for ultrasound image patterns according to the International Endometrial Tumor Analysis that may indicate potential ineffectiveness of the biopsy. 4) Assessment of effectiveness of an outpatient biopsy in detection of endometrial cancer. Methods: Observational prospective study on a non-selected population of women suspected of endometrial pathologies. Results: 116 endometrial aspiration biopsies have been analyzed. Diagnostic histopathological samples were obtained in 100 cases (86.2\%). There was no statistical significance in obtaining a non-diagnostic result of a biopsy in terms of the menopausal status, presence of uterine fibroids, occurrence of abnormal uterine bleeding, age, endometrial thickness and the number of deliveries. A large variety of ultrasound images were obtained according to the International Endometrial Tumor Analysis parameters. There were no clearly dominant patterns of endometrial ultrasound parameters in patients with non-diagnostic biopsy results. $100 \%$ of endometrial cancer cases were reported in postmenopausal patients with the history of abnormal uterine bleeding. The mean thickness of the endometrium was statistically the largest in this group: $16.2 \mathrm{~mm}(4-22.3 \mathrm{~mm})(p=0.025)$. Conclusions: An outpatient endometrial aspiration biopsy is an effective, low-impact procedure in case of indications for histopathological assessment of the endometrium.
\end{abstract}

Keywords: endometrial cancer, endometrial biopsy, abnormal uterine bleeding, suction curette, endometrium sampler

Streszczenie Cele badań: 1) Sprawdzenie skuteczności ambulatoryjnej biopsji aspiracyjnej z jamy macicy w uzyskiwaniu satysfakcjonującego materiału do oceny. 2) Badanie czynników ryzyka uzyskania niediagnostycznego materiału. 3) Poszukiwanie wzorców obrazu ultrasonograficznego według systemu International Endometrial Tumor Analysis, które mogą przemawiać za potencjalną nieskutecznością biopsji. 4) Ocena skuteczności biopsji ambulatoryjnej w wykrywaniu raka endometrium. Materiał i metody: Obserwacyjne badanie prospektywne na niewyselekcjonowanej populacji kobiet zgłaszających się do poradni ginekologicznej podejrzanych o patologie endometrium. Wyniki: Przeanalizowano 116 biopsji aspiracyjnych endometrium. Diagnostyczny wynik histopatologiczny udało się uzyskać w 100 przypadkach (86,2\%). Nie wykazano istotności statystycznej w uzyskiwaniu niediagnostycznego wyniku biopsji w aspekcie statusu menopauzalnego, obecności mięśniaków macicy, występowania nieprawidłowych krwawień macicznych, wieku, grubości endometrium oraz liczby przebytych porodów. Uzyskano dużą różnorodność obrazów ultrasonograficznych według parametrów International Endometrial Tumor Analysis. Nie stwierdzono jednoznacznie dominujących wzorców parametrów ultrasonograficznych endometrium u pacjentek z niediagnostycznym wynikiem biopsji. U wszystkich (100\%) badanych w wieku pomenopauzalnym $\mathrm{z}$ nieprawidłowymi krwawieniami macicznymi w wywiadzie ujawniono raka endometrium. Średnia grubość endometrium $\mathrm{w}$ tej grupie była istotnie statystycznie największa: $16,2 \mathrm{~mm}(4-22,3 \mathrm{~mm})(p=0,025)$. Wnioski: Ambulatoryjna biopsja aspiracyjna endometrium jest skutecznym, mało obciążającym postępowaniem w przypadku stwierdzenia wskazań do weryfikacji histopatologicznej endometrium.

Słowa kluczowe: rak endometrium, biopsja endometrium, nieprawidłowe krwawienia maciczne, łyżeczka ssąca, sonda do pobierania próbki endometrium 


\section{INTRODUCTION}

$\mathrm{I}$ ndications for the endometrial biopsy include: abnormal uterine bleeding during the postmenopausal period, abnormal endometrial sonogram (in particular - with additional risk factors of endometrial pathologies), and abnormal uterine bleeding in premenopausal patients ${ }^{(1,2)}$. All postmenopausal patients suffering from abnormal bleedings should be verified histopathologically due to the real risk of endometrial cancer, which is the most frequent cancer of the reproductive system in women in economically developed countries ${ }^{(3,4)}$. In Poland, it constitutes about $7 \%$ of cancer cases in women ${ }^{(5)}$. $90 \%$ of endometrial cancers develop after the age of 50 , most often in the sixth and seventh decade of life. Over the last years, the approach to methods of sampling material from the uterine cavity has changed. The literature shows a clear tendency to perform diagnostic procedures in the least invasive way ${ }^{(6)}$. Therefore, curettage of the cervical canal and the uterine cavity, once the first-line method requiring admission to the hospital and general anesthesia, is being replaced with less invasive methods of endometrial sample collection using such tools as Endorette or Pipelle. Such procedures do not require hospitalization or anesthesia and are well-tolerated by patients $s^{(7)}$. Therefore, we planned an observational prospective study on a non-selected population of women suspected of endometrial pathologies referred to the gynecologic clinic. The aims of our study include: 1) examining the effectiveness of an outpatient aspiration biopsy from the uterine cavity in the context of satisfactory sampling; 2) identification of possible risk factors of obtaining nondiagnostic samples; 3) search for ultrasound image patterns according to the International Endometrial Tumor Analy- sis (IETA) that may indicate potential ineffectiveness of the biopsy; 4) assessment of effectiveness of an outpatient biopsy in detection of endometrial cancer.

\section{MATERIAL AND METHODS}

The analysis concerned outpatient biopsies, which were performed at the Department of Gynecology and Oncology of the University Hospital in Krakow in 2017. Prior to the biopsy, the patients were informed about the possible risk of complications and expressed their written consent to participate in the study. The study was approved by the local ethics committee (KBET/227/B/2010). Before the qualification for an outpatient endometrial biopsy, a physical examination was performed and the body mass index (BMI) was calculated. Directly prior to the biopsy, a pelvic ultrasound examination was conducted, and analyzed in accordance with the IETA standards ${ }^{(8)}$. Sonography was carried out on a Voluson E6 ultrasound scanner equipped with a hybrid RIC 5-9 transducer with a frequency range of 5-9 MHz. Indications for the endometrial biopsy included: abnormal uterine bleeding during the postmenopausal period, abnormal endometrial sonogram in the absence of bleeding, and abnormal uterine bleeding in premenopausal patients. On the basis of the history, a detailed assessment of the risk factors was carried out. Suspicious ultrasound features of the endometrium according to IETA were analyzed along with possible additional uterine lesions that might have a potential connection with the difficulty of taking samples such as fibroids, or uterine anomalies ${ }^{(8,9)}$. In an ultrasound scan, endometrial thickness of more than $5 \mathrm{~mm}$ after menopause was considered suspicious, regardless of the presence of fluid in the uterine cavity, with additional risk factors such as obesity, diabetes, hypertension, tamoxifen medication, history of malignancy ${ }^{(10,11)}$. If the ultrasound pic-

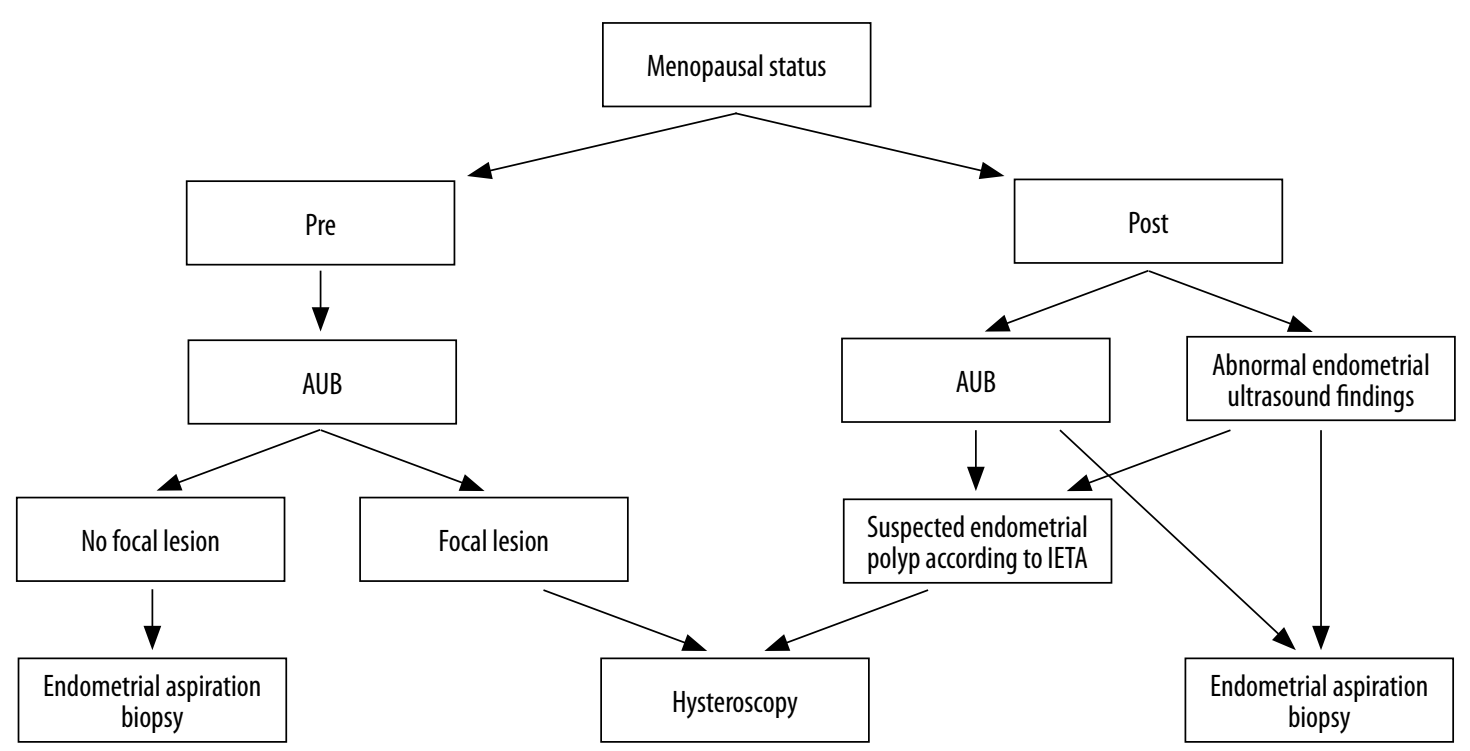

Fig. 1. The scheme of the study population. Abbreviations: AUB - abnormal uterine bleeding; IETA - International Endometrial Tumor Analysis 


\begin{tabular}{|c|c|}
\hline $\begin{array}{c}\text { Age [years]: } \\
\text { Mean } \\
\text { Min } \\
\text { Max } \\
\text { SD }\end{array}$ & $\begin{array}{c}56.88 \\
33 \\
91 \\
12.2\end{array}$ \\
\hline $\begin{array}{l}\text { BMI }\left[\mathbf{k g} / \mathbf{m}^{2}\right]: \\
\text { Mean } \\
\text { Min } \\
\text { Max } \\
\text { SD }\end{array}$ & $\begin{array}{l}22.66 \\
18.03 \\
56.4 \\
6.14\end{array}$ \\
\hline $\begin{array}{l}\text { Endometrial thickness [mm]: } \\
\text { Mean } \\
\text { Min } \\
\text { Max } \\
\text { SD }\end{array}$ & $\begin{array}{c}9.2 \\
1.3 \\
45 \\
6.16\end{array}$ \\
\hline $\begin{array}{l}\text { Bleeding }[\boldsymbol{n}(\%)]: \\
\text { Yes } \\
\text { No }\end{array}$ & $\begin{array}{l}75(64.7) \\
41(35.3)\end{array}$ \\
\hline $\begin{array}{l}\text { Diabetes [n (\%)]: } \\
\text { Yes } \\
\text { No }\end{array}$ & $\begin{array}{c}16(13.8) \\
100(86.2)\end{array}$ \\
\hline $\begin{array}{l}\text { Hypertension [ } \boldsymbol{n}(\%)] \text { : } \\
\text { Yes } \\
\text { No }\end{array}$ & $\begin{array}{l}56(48.3) \\
60(51.7)\end{array}$ \\
\hline $\begin{array}{l}\text { Menopausal status [ } \boldsymbol{n}(\%)] \text { : } \\
\text { Pre } \\
\text { Post }\end{array}$ & $\begin{array}{l}22(19) \\
94(81)\end{array}$ \\
\hline $\begin{array}{l}\text { Fibroids distorting the uterine cavity [ } \boldsymbol{n}(\%)] \text { : } \\
\text { Yes } \\
\text { No }\end{array}$ & $\begin{array}{l}31(26.7) \\
85(73.3)\end{array}$ \\
\hline $\begin{array}{c}\text { Deliveries [n (\%)]: } \\
0 \\
1 \\
\geq 2\end{array}$ & $\begin{array}{l}13(11.2) \\
25(21.6) \\
78(67.2)\end{array}$ \\
\hline
\end{tabular}

Tab. 1. Demographic and clinical analysis of patients included in the study

ture suggested the presence of an endometrial polyp according to IETA criteria (bright edge, single dominant vessel), the patient was withdrawn from the outpatient biopsy and was referred directly to hysteroscopy ${ }^{(8)}$. No other exclusion criteria were applied. In case of premenopausal patients, the potential cause of bleeding was assessed in accordance with the acronym PALM-COEIN (polyp, adenomyosis, leiomyoma, malignancy - coagulopathy, ovulatory disfunction, endometrial, iatrogenic, not yet classified) according to International Federation of Gynecology and Obstetrics (FIGO) ${ }^{(1)}$. In the absence of focal changes in the ultrasound picture or in case of a suspected functional cause (COEIN), the patients were qualified for the endometrial aspiration biopsy. If a focal lesion (polyp, intracavitary fibroid) was considered the cause, the patient was referred to hysteroscopy. The scheme of the study population is shown in Fig. 1.

Endometrial aspiration biopsy was performed with the Probet tool (Gynétics Services BVBA, Lommel, Belgium). All biopsies were performed without local or general anesthesia. The samples were put into containers with a formalin solution and sent to the Department of Pathomorphology for a further analysis. In case of a non-diagnostic outcome, the patients were referred to the outpatient clinic

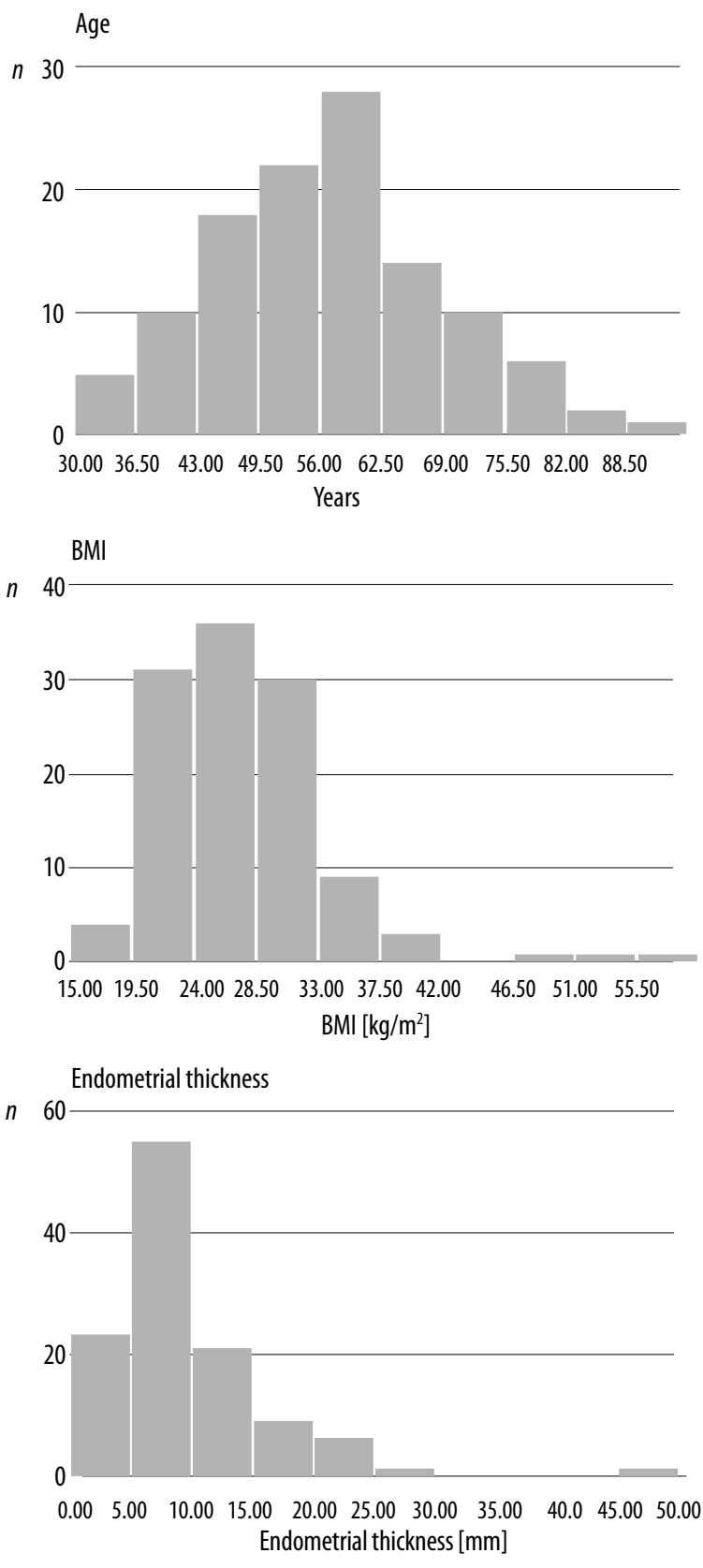

Fig. 2. Histograms of age distribution, BMI and endometrial thickness

for the re-evaluation of biopsy indications and a further investigation. Statistical analyzes were performed using the Statistica ver. 6.0 (StatSoft Ltd., Krakow, Poland). Cross tabulation tables with the chi-squared test were used for the categorization of variables, and the comparison of the means was performed with the non-parametric $U$ MannWhitney test for two independent groups.

\section{RESULTS}

The results of 116 outpatient endometrial biopsies were analyzed. The basic characteristics of the study population are shown in Tab. 1. 


\begin{tabular}{|c|c|c|c|}
\hline & $\begin{array}{l}\text { Diagnostic } \\
\text { result }\end{array}$ & $\begin{array}{l}\text { Non- } \\
\text { diagnostic } \\
\text { result }\end{array}$ & $\begin{array}{c}\text { Statistical } \\
\text { significance } \\
{[p]}\end{array}$ \\
\hline $\begin{array}{l}\text { Endometrial thickness } \\
\text { [mm]: } \\
\text { Mean } \\
\text { Min } \\
\text { Max } \\
\text { SD }\end{array}$ & $\begin{array}{c}8.84 \\
2 \\
26 \\
7.1\end{array}$ & $\begin{array}{l}9.25 \\
1.3 \\
45 \\
6.04\end{array}$ & 0.355 \\
\hline $\begin{array}{c}\text { Age [years]: } \\
\text { Mean } \\
\text { Min } \\
\text { Max } \\
\text { SD }\end{array}$ & $\begin{array}{c}62.44 \\
38 \\
91 \\
13.12\end{array}$ & $\begin{array}{c}55.99 \\
33 \\
85 \\
11.88\end{array}$ & 0.061 \\
\hline $\begin{array}{l}\text { Bleeding }[\boldsymbol{n}(\%)]: \\
\text { Yes } \\
\text { No }\end{array}$ & $\begin{array}{c}6(14.6) \\
10(13.3)\end{array}$ & $\begin{array}{l}35(85.4) \\
65(86.7)\end{array}$ & 0.847 \\
\hline $\begin{array}{l}\text { Menopausal status } \\
\text { [n (\%)]: } \\
\text { Pre } \\
\text { Post }\end{array}$ & $\begin{array}{c}2(9.1) \\
14(14.9)\end{array}$ & $\begin{array}{l}20(90.9) \\
80(85.1)\end{array}$ & 0.458 \\
\hline $\begin{array}{l}\text { Fibroids distorting the } \\
\text { uterine cavity [ } \boldsymbol{n}(\%)] \text { : } \\
\text { Yes } \\
\text { No }\end{array}$ & $\begin{array}{c}3(9.7) \\
13(15.3)\end{array}$ & $\begin{array}{l}28(90.3) \\
72(84.7)\end{array}$ & 0.423 \\
\hline $\begin{array}{l}\text { Deliveries [n(\%)]: } \\
\quad 0-2 \\
\quad \geq 3\end{array}$ & $\begin{array}{l}12(14.1) \\
4(12.9)\end{array}$ & $\begin{array}{l}73(85.9) \\
27(87.1)\end{array}$ & 0.866 \\
\hline
\end{tabular}

Tab. 2. The effectiveness of an outpatient aspiration biopsy from the uterine cavity in the context of satisfactory sampling
Abnormal uterine bleeding in 75 patients (64.7\%), and an abnormal endometrial sonogram without the history of bleeding of the remaining 41 patients $(35.3 \%)$ were the indications for the histopathological verification of the endometrium.

Histograms regarding the BMI distribution, the endometrial thickness and the age of patients are shown in Fig. 2. The mean BMI was the highest in the group of patients with endometrial cancer (33.7, range 23.1-52.3) with mean BMI 27.3 (range 18-56.4) of the remaining patients. In this respect, statistical significance was not demonstrated $(p=0.209)$.

\section{The effectiveness of an outpatient aspiration biopsy from the uterine cavity in the context of satisfactory sampling}

A diagnostic histopathological result was obtained in 100 cases $(86.2 \%)$; in $3(2.6 \%)$ the material obtained from the uterine cavity was too scant to be analyzed, in $13(11.2 \%)$ no material was obtained from the uterine cavity. The details are described in Tab. 2.

\section{Risk factors of ineffective sampling with the use of an outpatient biopsy}

Non-diagnostic biopsies were more frequently observed after menopause (14.9\% vs. 9.1\%). However, the menopausal
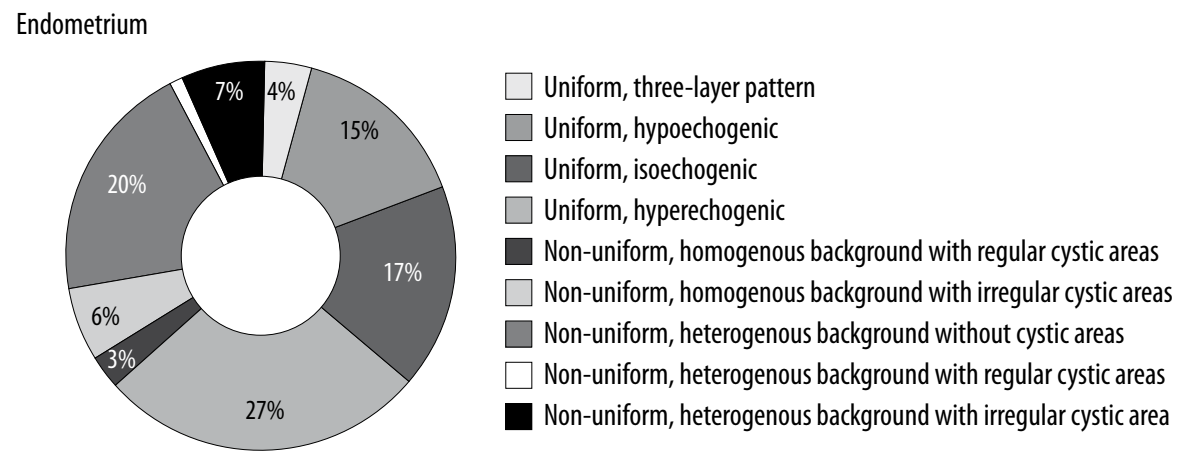

Endometrial-myometrial junction

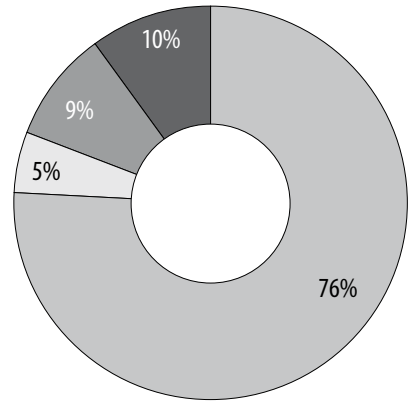

Midline

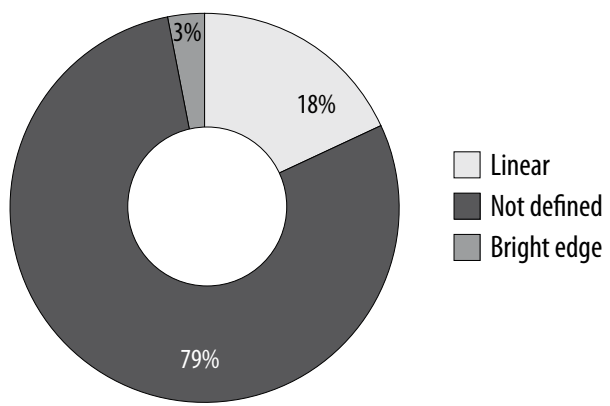

Fig. 3. Frequency of ultrasound parameters in successful biopsies: endometrial echogenicity, endometrial midline, and endometrial-myometrial junction 

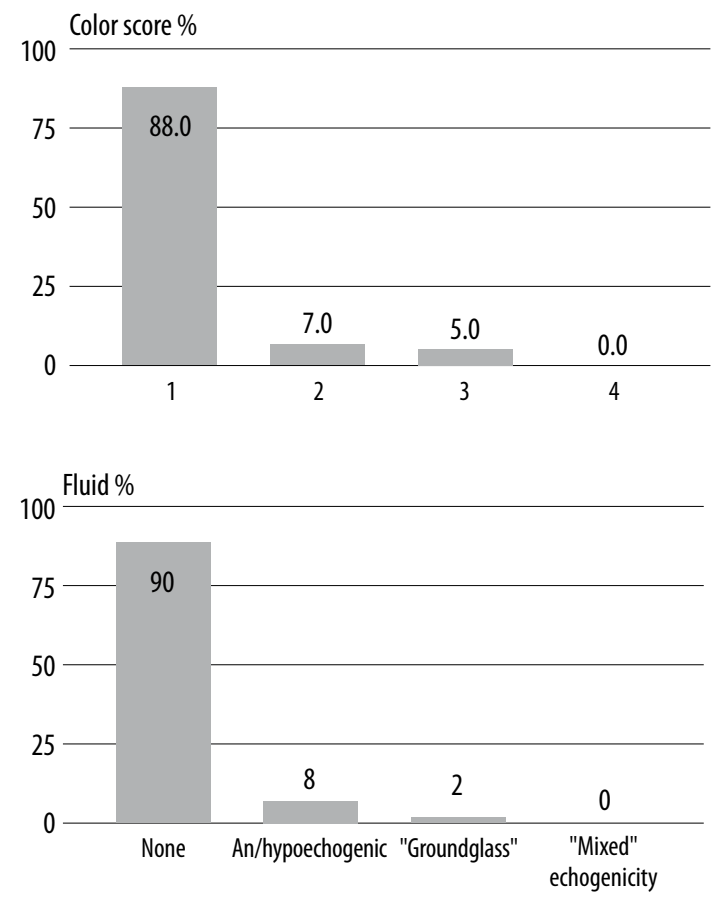

Fig. 4. Frequency of ultrasound parameters in successful biopsies: presence of fluid in the uterine cavity, vascularization within the endometrium status did not show statistical significance in this respect ( $p=0.458) .31$ patients $(26.7 \%)$ showed clinically significant uterine fibroids, which were defined as the presence of an intramural fibroid distorting the uterine cavity. In this group, 3 biopsies (8.68\%) turned out to be non-diagnostic compared to $13(15.3 \%)$ non-diagnostic biopsies in the group of patients without intramural fibroids. However, statistical significance was not demonstrated in this category $(p=0.423)$. Among 41 subjects with indications other than abnormal reproductive tract bleeding, there were $6(14.6 \%)$ non-diagnostic biopsies compared to $10(13.3 \%)$ non-diagnostic biopsies in the group of patients with the bleeding $(n=75)(p=0.847)$. There was no statistical significance in terms of age, endometrial thickness and number of deliveries (Tab. 2).

\section{Search for ultrasound image patterns indicating an ineffective sample collection}

Ultrasound parameters based on IETA criteria in case of successful biopsies are presented in Figs. 3 and 4.

Ultrasound parameters based on IETA criteria in case of non-diagnostic biopsies are presented in Figs. 5 and 6.

As shown in Figs. 3-6, the distribution of parameters according to IETA in case of diagnostic and non-diagnostic biopsies is similar.

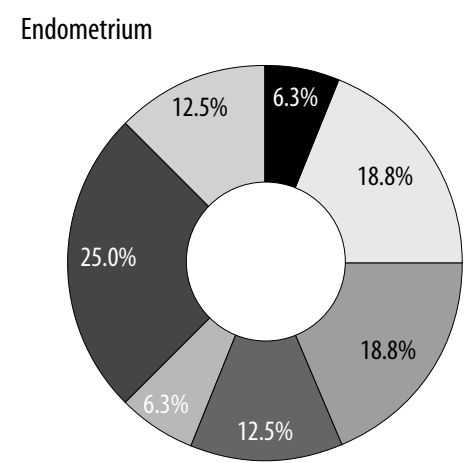

Uniform, three-layer pattern

Uniform, hypoechogenic

Uniform, isoechogenic

Uniform, hyperechogenic

Non-uniform, homogenous background with regular cystic areas

Non-uniform, heterogenous background without cystic areas

Non-uniform, heterogenous background with irregular cystic areas

Endometrial-myometrial junction

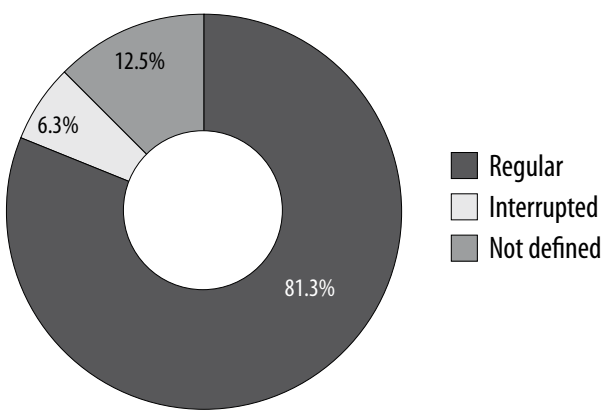

Midline

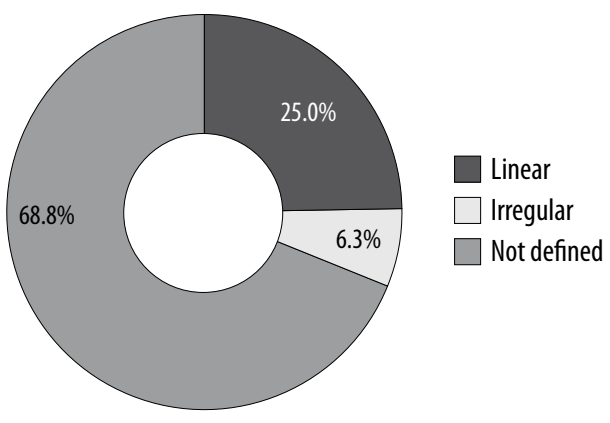

Fig. 5. Frequency of ultrasound parameters in non-diagnostic biopsies: endometrial echogenicity, endometrial midline, and endometrialmyometrial junction 

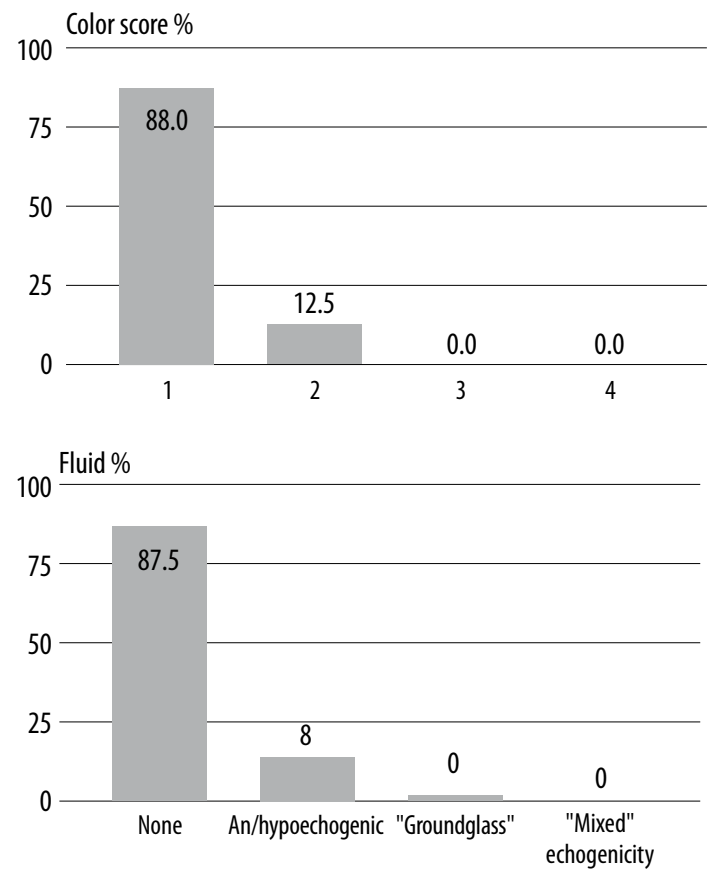

Fig. 6. Frequency of ultrasound parameters in non-diagnostic biopsies: presence of fluid in the uterine cavity, vascularization within the endometrium

\section{Efficacy in detecting endometrial cancer and histological diagnosis}

$100 \%$ of endometrial malignancies were diagnosed in postmenopausal patients with the history of abnormal uterine bleeding. The mean endometrial thickness was statistically the largest in this group: $16.2 \mathrm{~mm}$ (range 4-22.3 mm) $(p=0.025)$, although in one case of endometrial cancer the thickness equaled $4 \mathrm{~mm}$. In the remaining subjects, the mean endometrial thickness was $8.7 \mathrm{~mm}$ (range 1.3-45 $\mathrm{mm}$ ). The list of histopathological reports from outpatient biopsies is shown in Tab. 3.

Among patients with non-diagnostic histopathological findings, in 2 cases hysterectomy was performed for indications other than bleeding. Histopathology reporting showed an endometrial polyp in one case, and normal endometrium in the other. In 4 cases, endometrial curettage was performed, showing an endometrial polyp in 2 cases, and normal endometrium in 2 cases in histopathology.

\begin{tabular}{|l|c|}
\hline Histopathology & $\boldsymbol{n ( \% )}$ \\
\hline Normal endometrium & $87(75)$ \\
\hline Sample too scant to analyze & $3(2.6)$ \\
\hline No sample from the uterine cavity & $13(11.2)$ \\
\hline Endometrial polyp & $6(5.2)$ \\
\hline Endometrial cancer & $7(6.0)$ \\
\hline
\end{tabular}

Tab. 3. Distribution of histopathological results in the examined group of patients
The remaining 10 patients were not referred to the subsequent diagnostic procedure. After re-examining the indications, they were qualified for a follow-up and instructed about the need to contact a gynecologist in the event of abnormal uterine bleeding.

\section{DISCUSSION}

Similarly to other publications, the results of our analysis showed satisfactory biopsy performance in obtaining diagnostic material for histopathological evaluation at the level of $86.2 \%$. We obtained better efficacy than Adambekov et al. (77.11\%), Piątek et al. (83.01\%), or Machado et al. $(83.91 \%)^{(9,12,13)}$, while Madari et al. and Rauf et al. ${ }^{(7,14)}$ reported higher effectiveness in obtaining a satisfactory sample to evaluate $-87 \%$ and $98 \%$, respectively. In our study, we obtained full diagnostic efficacy of endometrial cancer by detecting 7 cases of this malignancy using an outpatient biopsy in the group of 116 patients, despite the cases of ineffective material collection ${ }^{(15)}$.

An attempt to identify the risk factors of obtaining nondiagnostic material did not produce statistically significant results. Factors such as infertility, no history of abnormal bleeding, endometrial thickness, patient's age, menopausal status or fibroids distorting the uterine cavity, although subjectively hindered sampling, turned out to be statistically insignificant as risk factors of obtaining a non-diagnostic material ${ }^{(16-19)}$.

Visser et al. obtained statistically significantly lower frequency of diagnostic biopsies in nulliparas and in older patients $^{(19)}$. Bakour et al. in turn, in this aspect showed a dependence of the endometrial thickness below $5 \mathrm{~mm}$ as an unfavorable factor for effective material collection. As in our analysis, it did not show such a correlation in the case of age and menopausal status ${ }^{(18)}$. In our study, we obtained a large variety of ultrasound images according to IETA parameters in patients referred to the histopathological verification. Such an observation makes it impossible to determine uniquely dominant patterns of endometrial ultrasound parameters in patients with non-diagnostic biopsy results. The strengths of our study included an unselected screening group of patients referred to the gynecology clinic, and the fact that the study was carried out prospectively. Weak points were the loss of 10 patients from the follow-up, in whom we failed to obtain a diagnostic result, and a relatively small number of patients included in the study, hence probably no statistical significance in risk factors such as patients age, which was obtained is number of previous studies. Based on our observations, it can be concluded that the performance of an outpatient endometrial aspiration biopsy is justified as first-line diagnostics. An unquestionable advantage of such a procedure is the possibility of taking the material immediately after finding the abnormality. Treatments of this type do not require any preparation on the part of the patient, the determination of laboratory tests, hospitalization or any involvement of the 
staff of the operating room. Therefore, they can considerably accelerate the moment of diagnosis and, at the same time, significantly reduce the costs of the basic diagnostics ${ }^{(6)}$. This is particularly important considering the large number of patients referred to the hospital for the purpose of the histopathological verification of the endometrium. Even if receiving a non-diagnostic sample results from outpatient biopsies, this method does not delay final diagnostic process remarkably when subsequent more detailed diagnostic and therapeutic procedures are planned.

In addition, this procedure does not expose the patient to the risks associated with general anesthesia and is generally well-tolerated $^{(7)}$. The risk of perioperative complications of an outpatient biopsy is very low ${ }^{(20)}$, and in our material no were encountered. Considering the fact that the amount of sampling material obtained by means of an outpatient biopsy is lower than in curettage and that the material is collected without targeting, we believe that in the situation of a correct histopathological result and further bleeding, it is necessary to deepen the diagnostics in the form of curettage or hysteroscopy.

\section{CONCLUSION}

It can be assumed that the performance of an outpatient endometrial biopsy is an effective, low-impact procedure in case of indications for histopathological examination of the endometrium.

\section{Conflict of interest}

No authors have any relevant conflicts of interest to this published work.

\section{Funding/Support and role of the sponsor}

This research did not receive any specific grant from funding agencies in the public, commercial, or not-for-profit sectors.

\section{References}

1. Munro MG, Critchley HOD, Broder MS et al.; FIGO Working Group on Menstrual Disorders: FIGO classification system (PALM-COEIN) for causes of abnormal uterine bleeding in nongravid women of reproductive age. Int J Gynaecol Obstet 2011; 113: 3-13.

2. Soliman PT, Oh JC, Schmeler KM et al.: Risk factors for young premenopausal women with endometrial cancer. Obstet Gynecol 2005; 105: 575-580.

3. Visser NCM, Sparidaens EM, van den Brink JW et al.: Long-term risk of endometrial cancer following postmenopausal bleeding and reassuring endometrial biopsy. Acta Obstet Gynecol Scand 2016; 95: 1418-1424

4. Dimitraki M, Tsikouras P, Bouchlariotou S et al.: Clinical evaluation of women with PMB. Is it always necessary an endometrial biopsy to be performed? A review of the literature. Arch Gynecol Obstet 2011; 283: 261-266.
5. Wojciechowska U, Didkowska J: Zachorowania i zgony na nowotwory złośliwe w Polsce. Krajowy Rejestr Nowotworów, Centrum Onkologii - Instytut im. Marii Skłodowskiej-Curie. Available from: http://onkologia.org.pl/raporty/ [cited: 23 July 2018].

6. Sanam M, Majid MMK: Comparison the diagnostic value of dilatation and curettage versus endometrial biopsy by Pipelle a clinical trial. Asian Pac J Cancer Prev 2015; 16: 4971-4975.

7. Rauf R, Shaheen A, Sadia S et al.: Outpatient endometrial biopsy with Pipelle vs diagnostic dilatation and curettage. J Ayub Med Coll Abbottabad 2014; 26: 145-148.

8. Leone FP, Timmerman D, Bourne T et al.: Terms, definitions and measurements to describe the sonographic features of the endometrium and intrauterine lesions: a consensus opinion from the International Endometrial Tumor Analysis (IETA) group. Ultrasound Obstet Gynecol 2010; 35: 103-112.

9. Adambekov S, Goughnour SL, Mansuria S et al.: Patient and provider factors associated with endometrial Pipelle sampling failure. Gynecol Oncol 2017; 144: 324-328.

10. Jokubkiene L, Sladkevicius P, Valentin L: Transvaginal ultrasound examination of the endometrium in postmenopausal women without vaginal bleeding. Ultrasound Obstet Gynecol 2016; 48: 390-396.

11. Van den Bosch T, Van Schoubroeck D, Domali E et al.: A thin and regular endometrium on ultrasound is very unlikely in patients with endometrial malignancy. Ultrasound Obstet Gynecol 2007; 29: 674-679.

12. Piątek S, Panek G, Wielgoś M: Assessment of the usefulness of pipelle biopsy in gynecological diagnostics. Ginekol Pol 2016; 87: 559-564.

13. Machado F, Moreno J, Carazo M et al.: Accuracy of endometrial biopsy with the Cornier pipelle for diagnosis of endometrial cancer and atypical hyperplasia. Eur J Gynaecol Oncol 2003; 24: 279-281.

14. Madari S, Al-Shabibi N, Papalampros $\mathrm{P}$ et al.: A randomised trial comparing the $\mathrm{H}$ Pipelle with the standard Pipelle for endometrial sampling at 'no-touch' (vaginoscopic) hysteroscopy. BJOG 2009; 116: 32-37.

15. Visser NCM, Reijnen C, Massuger LFAG et al.: Accuracy of endometrial sampling in endometrial carcinoma: a systematic review and meta-analysis. Obstet Gynecol 2017; 130: 803-813.

16. Williams AR, Brechin S, Porter AJ et al.: Factors affecting adequacy of Pipelle and Tao Brush endometrial sampling. BJOG 2008; 115: 1028-1036.

17. Kandil D, Yang X, Stockl T et al.: Clinical outcomes of patients with insufficient sample from endometrial biopsy or curettage. Int J Gynecol Pathol 2014; 33: 500-506.

18. Bakour SH, Khan KS, Gupta JK: Controlled analysis of factors associated with insufficient sample on outpatient endometrial biopsy. BJOG 2000; 107: 1312-1314.

19. Visser NC, Breijer MC, Herman MC et al.: Factors attributing to the failure of endometrial sampling in women with postmenopausal bleeding. Acta Obstet Gynecol Scand 2013; 92: 1216-1222.

20. Singh P: Abnormal uterine bleeding - evaluation by endometrial aspiration. J Midlife Health 2018; 9: 32-35. 